\title{
Z historie Ústavu soudního inženýrství Vysokého učení technického v Brně - III
}

\author{
From the History of the Institute of Forensic Engineering, \\ Brno University of Technology - Part III
}

Albert Bradáč, emeritní profesor*

\begin{abstract}
Abstrakt
V předchozích příspěvcích jsme se zabývali počátečním obdobím vzniku ústavu do roku 1970, včetně stručné znalecké analýzy některých nehod, zejména železničních. Do problematiky ústavu spadala od počátku také technická analýza dopravních nehod silničních; ukažme si proto jejich problematiku z hlediska historie oboru obecně, rozvoj teorie a nakonec zajímavé př́iklady nehod řešené ústavem, zejména $\mathrm{v}$ prvopočátcích. Připojena je také problematika oceňování vozidel. Jedná se o př́ípady již dávné, $\mathrm{k}$ nimž již většinou není podrobná dokumentace; čtenáři jistě prominou zjednodušené názorné nákresy, vyhotovené v programech, jež jsou k dispozici v MS Office-Vložit obrazce v MS Word a Malování.
\end{abstract}

Klíčová slova: silniční nehoda, znalec, znalecký posudek, znalecký ústav, výchova soudních znalců, analýza silniční nehody.

Po zrušení platnosti zákona č. 47/1959 Sb., o úpravě právních poměrů znalců a tlumočníků, spolu s prováděcí vyhláškou č. 193 Ú.1. ${ }^{1)}$, došlo od 1. 7. 1967 zákonem č. 36/1967 Sb., o znalcích

\footnotetext{
1) Cílem zákona a vyhlášky z roku 1959, kdy probíhala konečná etapa rušení soukromých živností (viz nápis na bráně borců na spartakiádě 1960: „Socialismus v naší vlasti zvítězil“), bylo dle důvodové zprávy „vymýcení soukromopodnikatelských způsobů při provádění znaleckých a tlumočnických úkonů“. Neexistovali znalci jako osoby ani seznamy znalců; dožadující orgány požadovaly od orgánů státní správy a organizaci socialistického sektoru, aby jim byla označena osoba, která má provés znalecký úkon. Výjimečně, ve zvlášt' obtížných případech, byla dána možnost požádat o znalecký úkon státní ústav nebo státní orgán. Výběr osoby znalce spočíval na dožádaném orgánu resp. organizaci. Pověřené osoby posudky zpracovávaly $\mathrm{v}$ rámci pracovního poměru u svého zaměstnavatele; za obsah posudku nesly osobně plnou odpovědnost, fakturaci ovšem prováděl zaměstnavatel. Tato úprava měla za následek výrazné prodloužen lhůt zpracování posudků a pokles jejich kvality. Organizace nebyly na vypracování posudků zainteresovány, znalci se stř́ídali a nenabývali potřebných zkušeností. Také odměňování za znaleckou činnost nebylo zcela v pořádku. Úprava proto vydržela jen do roku 1967.
}

\begin{abstract}
In previous articles, we dealt with the initial period of the establishment of the institute until 1970, including a brief expert analysis of some accidents, especially railway accidents. From the very beginning, the institute also included technical analysis of road traffic accidents; let us therefore show their problems from the point of view of the history of the field in general, the development of theory and finally interesting examples of accidents solved by the institute, especially in the beginning. The issue of vehicle valuation is also attached. These are cases long ago, for which there is usually no detailed documentation; readers will certainly forgive the simplified illustrative drawings, made in the programs available in MS Office - Insert Shapes in MS Word and Paint.
\end{abstract}

Keywords: road accident, expert, expert opinion, expert institute, education of forensic experts, road accident analysis.

a tlumočnících, spolu s prováděcí vyhláškou č. 37/1967 Sb., k návratu znalců jako samostatných osob, nově jmenovaných podle zákona; uzákoněny byly také znalecké ústavy, vytvořeny byly seznamy znalců a znaleckých ústavů. Chyběla zde ovšem kontinuita znalostí, přerušená předchozím zákonem, naprríklad znaleckou činnost $\mathrm{k}$ problematice analýzy nehod vykonávali $\mathrm{z}$ velké části učitelé autoškol jen na základě svých praktických zkušeností; nebylo zde místo, jež by rozvíjelo metodiku vlastní analýzy. Na školách se vyučovala jen konstrukce a chování automobilů v běžném provozu, chování před a během nehodového děje nebylo předmětem výuky.

Nedostatečná kvalifikace znalců se projevovala občas velmi závažně. Př́íkladem může být nehoda u Hradce Králové, mimo obec, na silnici I. třídy směr Praha. Z vedlejší silnice na hlavní vyjížděla doleva nákladní Tatra 111 valník. Zprava přijížděla osobní Tatra 603 se dvěma důstojníky vnitra; její řidič začal brzdit, ale po 105 metrech brzdných stop narazila T603 levým bokem zezadu na T111. Došlo k utržení střechy T603 ve výši oken, obě osoby utrpěly smrtelné zranění v horní části hlavy. 
Přibraný znalec spočetl podle vztahu pro rychlost na začátku brzdění zpomalením $a=6 \mathrm{~m} \cdot \mathrm{s}^{-2}$ podle vztahu:

$$
v=\sqrt{2 a s}=\sqrt{2 \cdot 6 \cdot 105}=35,5 \mathrm{~m} \cdot \mathrm{s}^{-1}=128 \mathrm{~km} \cdot \mathrm{h}^{-1} .
$$

Připočetl odhadnutou nárazovou rychlost T603 na T111 ve výši $50 \mathrm{~km} / \mathrm{h}$ a dospěl k výchozí rychlosti T603 na začátku stop ve výši $128+50=178 \mathrm{~km} \cdot \mathrm{h}^{-1}$. Otázka soudu na znalecký ústav pak zněla: když v technickém průkazu T603 je uvedena maximální rychlost $160 \mathrm{~km} \cdot \mathrm{h}^{-1}$ (což uvedl i původní znalec ve svém posudku), jakými úpravami, např́klad motoru, převodovky aj., lze dosáhnout rychlosti $178 \mathrm{~km} \cdot \mathrm{h}^{-1}$ ?

Pan inženýr Smrček tomu říkal „znalecká chyba č. 1“ - sečítat rychlosti. Sčítají se energie - energie zmařená brzděním a energie nárazová. Je pak třeba sečítat pod odmocninou dle vztahu (nárazová rychlost $v_{x}=50 \mathrm{~km} \cdot \mathrm{h}^{-1}=13,9 \mathrm{~m} \cdot \mathrm{s}^{-1}$ )

$$
\begin{gathered}
v=\sqrt{2 a s+v_{x}^{2}}=\sqrt{2 \cdot 6 \cdot 105+13,9^{2}} \mathrm{~m} \cdot \mathrm{s}^{-1}={ }^{2)} \\
=38,12 \mathrm{~m} \cdot \mathrm{s}^{-1}=137 \mathrm{~km} \cdot \mathrm{h}^{-1} .
\end{gathered}
$$

Jiný př́klad neodbornosti, dokonce u odborného asistenta vysoké školy dopravní. Po velmi pracném výpočtu excentrického střetu vozidel (nebyly ještě PC) mu vyšla výsledná rotace vozidla po střetu cca 6 otáček za sekundu. Bohužel si ovšem neuvědomil, že výsledek není v otáčkách, ale v radiánech za sekundu, takže při jedné otáčce $\left(=360^{\circ}=2 \pi\right.$ radiánů) nikoliv 6 ot $/ \mathrm{s}$, ale $6 \mathrm{rad} / \mathrm{s}$, tedy jen cca jedna otáčka za sekundu.

Kvalifikace znalců pro analýzu silničních nehod se začala postupně měnit zásluhou pana inženýra Jiřího Smrčka respektive Ústavu soudního inženýrství VUT v Brně. První úkol ve výchově specializovaných technických znalců byl dán ministerstvu školství usnesením vlády ze dne 12. 10. 1966 při projednávání zprávy o rozboru bezpečnosti silničního provozu a o hlavních směrech k jejímu zlepšení, a to „zabezpečit na vysokých školách počínaje šk. r. 1967/68 postgraduální studium soudních znalců v oboru silničního provozu“. Tímto bylo pověřeno Vysoké učení technické v Brně, na němž právě v této problematice působil Ing. Smrček, jenž pro tehdejší postgraduální kursy sestavil tým odborníků z celého VUT i externích; jmenujme např́klad:

- Doc. Ing. Dr. Jaroslav Kovařík (Fakulta strojní, Dynamika pohybu motorových vozidel),

- Ing. Jiř́i Meduna (FS, Aplikovaná mechanika),

- Doc. RNDr. Jan Schwarz (FS, Vybrané statě z fyziky a matematiky),

- JUDr. Miroslav Merc (Krajský dopravní prokurátor, Základy trestního práva),

- Ing. Jiří Smrček (ÚSI, Soudní inženýrství, Práva a povinnosti znalců, Analýza silničních nehod),

- Ing. Pavel Krejčíř (FS, Konstrukce a životnost motorových vozidel a jejich zkoušení),

- Ing. Drahomír Navrátil (ČSAO Brno, Diagnostika vozidel a technologie opravárenství),

2) Jen pro zajímavost: osádka T603 vyjela z Prahy časně ráno, před Hradcem Králové byli před polednem; kde byli mezitím, se nepodařilo zjistit. Přri pitvě bylo řidiči opakovaně naměřeno přes pět promile alkoholu, spolujezdci přes jedno. Jejich poloha ve vozidle byla zjištěna podle otisků bezpečnostních pásů. Dohlednost z T603 na T111 do křižoatky byla zjištěna v hodnotě 444 m. Řidič T111 namítal, že osádka T603 byla opilá, ale podle zanechaných stop řidič T603 jednal jako střízlivý (podle délky reakční doby a podle směru brzdně smykových stop).
- Ing. Stanislav Baláš (ext., Autoelektrika v autoopravárenství),

- Doc. Ing. Dušan Nop, CSc. (Fakulta stavební, Vybrané statě z dopravního inženýrství, Psychologie řidiče),

- Prof. MUDr. Janoušek, CSc. (Ústav soudního lékařství Masarykovy univerzity Brno, Vybrané statě ze soudního lékařství).

V současné době probíhá na ÚSI již 41. běh tohoto specializačního studia, jež se samozřejmě v průběhu doby průběžně aktualizuje o poslední poznatky, včetně využívání výpočetní techniky, zejména simulačních programů; celkový počet úspěšných absolventů přesáhl 670. Jeden kurs znalců specializace silničních nehod uspořádali $\mathrm{v}$ šedesátých letech minulého století na VŠSE (nyní ZČU) v Plzni absolventi prvního kursu ÚSI. Na ústavu byly také k této problematice vytvářeny studijní texty a znalecké standardy; seznam je uveden na konci tohoto př́spěvku.

V roce 1985 se rozhodlo české ministerstvo spravedlnosti provést přezkoušení znalců - analytiků silničních nehod. Poněvadž ovšem k této problematice neexistovaly osnovy ani jiný přehled látky, jež by měla být předmětem zkoušek, dalo ministerstvo na doporučení ÚSI VUT v Brně tyto podklady vyhotovit a pověřilo tím právě ústav. Byl sestaven kolektiv 17 spoluautorů a 10 odborných recenzentů z VUT, Ministerstva spravedlnosti, Nejvyššího soudu, Generální prokuratury i z praxe. Byla vytvořena dvoudílná Příručka znalce - analytika silničních nehod [16], jejíž tisk a distribuci provedl Dům techniky ČSVTS v Ostravě. Př́ručka o rozsahu 550 stran A4 obsahovala mj. problematiku právní včetně práv a povinností znalců, mechaniku, dynamiku pohybu motorových vozidel, metrickou analýzu fotografí dopravních nehod, metodiku nálezu a posudku, specifiku analýzy nehod a oceňování motorových vozidel.

Znalcům byla dána lhůta půl roku ke studiu, následně byla vytvořena komise ze zástupců Ministerstva spravedlnosti (JUDr. Libuše Provazníková), Nejvyššího soudu (JUDr. Jankovský), Generální prokuratury (JUDr. Veselý), za ÚSI pak Ing. Pavel Krejčír a autor tohoto příspěvku. Komise přezkoušela členy poradních sborů předsedů jednotlivých krajských soudů; tito pak přezkoušeli ostatní znalce v kraji. Třetina znalců po obdržení Příručky požádala o vyškrtnutí ze seznamu znalců; výsledkem akce byla podstatně vyšší úroveň a sjednocená metodika znalecké analýzy vzniku a průběhu silničních nehod.

Vyšší stupeň vzdělání, kterým je vědecká výchova oboru Soudní inženýrství pro znalce technických a ekonomických oborů, je na základě akreditace Ministerstva školství, mládeže a tělovýchovy od akademického roku 1995/96 uskutečňován na Vysokém učení technickém v Brně formou doktorského studijního programu. První akreditaci specializace analýzy nehod obdrželo VUT pro Fakultu strojního inženýrství ve spolupráci s ÚSI, od roku 2008 pak je akreditace oboru soudní inženýrství pro ÚSI jako samostatný vysokoškolský ústav ve spolupráci s fakultami VUT. Prvním úspěšným doktorandem specializace ASN byl pan Ing. Petr Ptáček, Ph.D., jenž zpracoval zajímavou disertaci na téma „Možnost využití řidičských trenažérů pro znalecké zkoumání chování řidičů pro analýzu silničních nehod““. Podstatou bylo ověřit délku reakční doby řidičů $\mathrm{v}$ různých situacích na řidičském trenažéru a porovnat ji s reakční dobou v reálných situacích, aby bylo možno validovat reakční dobu zjištěnou na trenažéru u řidičů pod vlivem alkoholu. Pokusů k tomu se zúčastnili frekventanti dvou 
kursů ASN za dohledu dopravních psychologů a soudních lékařů. Firma dodávající trenažery po dohodě s doktorandem zapůjčila dva trenažery a vytvořila program simulující jízdu, při které vznikaly nečekané překážky - divočák či srna z př́íkopu, autu vpředu spadne krabice, návěs v protisměru začne vybočovat do jízdní dráhy řidiče. V závislosti na čase od okamžiku vzniku podnětu/překážky byl zaznamenáván průběh pohybu pedálů a volantu. Frekventanti absolvovali jízdu na trenažéru nejprve střízliví, pak postupně se zvyšujícím se množstvím alkoholu v krvi (alkohol si přinesli sami, hladinu měřila soudní lékařka, maximum bylo 2,9 promile; při této hladině řidič projel na projekčním plátně vybočeným návěsem a ani o tom nevěděl). Autor tohoto př́spěvku sloužil celý den jako porovnávací vzorek bez vlivu. Hlavním výsledkem bylo zejména porovnání rozptylu reakční doby u různých stř́izlivých řidičů s následným brzděním na trenažéru s výsledky dřivějších měřeni velkých automobilek v reálném provozu; výsledky se významně shodovaly. Vedlejším produktem byly grafy závislosti reakční doby a chování řidiče na obsahu alkoholu v krvi; zajímavým vedlejším zjištěním, bohužel jen na neprůkazně velkém souboru (malý počet hodnot) bylo, že při velmi malých množstvích alkoholu v krvi se reakční doba zkracuje, ale způsob řešení situace se zhoršuje.

Dalšími zajímavými tématy ve specializaci ASN byly např́iklad:

- Modelování pohybu vozidla při analýze silničních nehod vyhýbací manévr (Ing. Robert Kledus, Ph.D., 2003).

- Problematika znaleckého posuzování střetu vozidla s chodcem za snížené viditelnosti (Ing. František Kropáč, Ph.D., 2003).

- Možnosti určení střetové rychlosti vozidla při znalecké analýze nehod s chodci (Ing. Pavel Pustina, Ph.D., 2003).

- Optické metody detekce nezřetelných stop na vozovce při znalecké analýze silničních nehod (Ing. Vlastimil Rábek, Ph.D., 2003).

- Modelování pohybu vozidla - vyhýbací manévr (Ing. Albert Bradáč, Ph.D., 2005).

- Problematika znalecké analýzy jízdy a brzdění vozidla v obecném prostorovém oblouku (Ing. Aleš Vémola, Ph.D., 2005).

- Komplexní systém pro analýzu silniční nehody - střet dvou automobilů na křižovatce (Ing. Bc. Marek Semela, Ph.D., 2009).
- Analýza reakcí řidičů na složené podněty (Ing. Aleš Kaplánek, Ph.D., 2010).

- Vybrané problémy znalecké analýzy spatření chodců řidičem vozidla za viditelnosti snížené tmou (Ing. Jaroslav Sedlák, Ph.D., 2013).

Snahou ústavu bylo také šírit nové poznatky mezi znaleckou obec. V minulém režimu bylo ovšem prakticky nemožné založit odborný časopis; nabídl se však absolvent ÚSI pan Ing. Zdeněk Pěnička, šéfredaktor časopisu České státní pojišt'ovny „Zábrana škod“, ve kterém byla zřízena rubrika „Informace znalcům“; z oboru ASN zde byla např́iklad řešena otázka příčného přemístění oproti brzdění „Brzdit nebo se vyhnout?“.

Ukažme si nyní na př́kladech ústavem dř́ve řešených posudků vývoj problematiky ASN; autor připomíná, že jsou z doby předpočítačové, bez plotterů a simulačních programů, kdy nejlepší technikou byly kapesní kalkulačka, výjimečně programovatelný kapesní kalkulátor HP, pásmo, fotoaparát na svitkový film a mechanický psací stroj.

Jedním z prvních posudků, na nichž se autor podílel, bylo posouzení příčiny havárie osobního automobilu v jedné obci na Slovensku v pravotočivé pravoúhlé zatáčce na povrchu pokrytém nánosem při svozu cukrové řepy. Automobil po převrácení ze svahu skončil mimo vozovku, natočený doprava $\mathrm{k}$ původnímu směru jízdy, s ulomeným kulovým čepem řízení u levého předního kola. Řidič se hájil tím, že právě kvůli prasklému čepu nemohl zatočit a kvůli tomu vyjel ze zatáčky. Nasvědčovaly tomu také čtyři stopy na vozovce, označené na náčrtku policie po dvojicích jako stopy levých kol a stopy pravých kol. Metrickou analýzou fotografie těchto stop bylo ovšem zjištěno, že vzdálenost těchto dvojic stop neodpovídá rozchodu kol, ale je větší, blížící se spíše rozvoru náprav, takže vozidlo sice zatočilo, ale adheze nestačila pro průjezd zatáčkou a díky setrvačné síle vozidlo vyjelo ze silnice bokem. Prasklý čep byl pak až důsledkem nárazu vozidla levou přední částí z boku na hranu př́kopu, čemuž odpovídala i deformace karoserie a LP kola.

Dalším příkladem může být př́ipad okresního prokurátora ze Slovenska, jenž si od příslušníka VB koupil starší osobní automobil Škoda 445 Octavia (dále jen Octavia) a vypravil se s ním na silnici (i když měl řidičský průkaz pouze na malý motocykl). $\mathrm{Na}$ křižovatce, na kterou přijížděl po vedlejší silnici označené

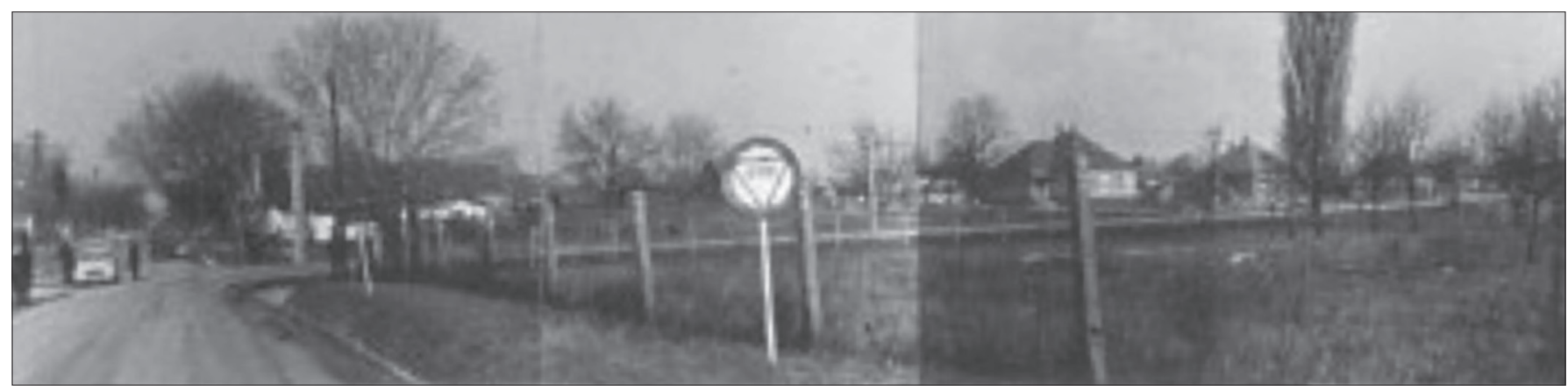

Obr. 1 Kruhová panoramatická fotografie (od policie, v době vyšetrovacího pokusu, kvalita podle tehdejších možností) - výhled z vedlejši silnice, z níz přijiždèla Octavia, na hlavni silnici do mist, odkud zprava přijižděla vozidla 1000 MB a Š 100 . Pohled z mista výhledu svědka motocyklisty $v$ okamžiku střetu automobilů.

Fig. 1 Circular panoramic photo (from the police, at the time of the investigation, quality according to the possibilities at the time) - view from the side road from which the Octavia came, on the main road to the places from where $1000 \mathrm{MB}$ and $\breve{S} 100$ vehicles came from the right. witness motorcyclists at the moment of a car collision. 
svislou dopravní značkou „Stůj, dej přednost v jízdě!“, došlo ke střetu jeho vozidla s vozidlem Škoda 100 (dále jen Š100), jež přijelo zprava a předjiždělo právě vozidlo Škoda $1000 \mathrm{MB}$ (dle jen Š1000MB). Postavení po nehodě a poškození vozidel jsou zřejmá z obr. 2 až 5 .

Ohledat místo nehody přijeli příslušníci VB, které ovšem řidič Octavie poslal pryč a zavolal př́íslušníka, od kterého automobil koupil. Následně zde byly dvě verze nehody a úkolem ústavu bylo posoudit jejich technickou prrijatelnost:

- Verze řidiče Š100: předjížděl vozidlo Š1000MB, když zleva proti němu vyjelo vozidlo Octavia. Snažil se vyhnout, uhnul mírně doprava k předjižděnému vozidlu, ale došlo prakticky čelně ke střetu s Octavií. Tuto verzi podporovala výpověd' řidiče malého motocyklu, jenž ke křižovatce přijížděl z vedlejší silnice za Octavií, s tím, že Octavia před vjezdem

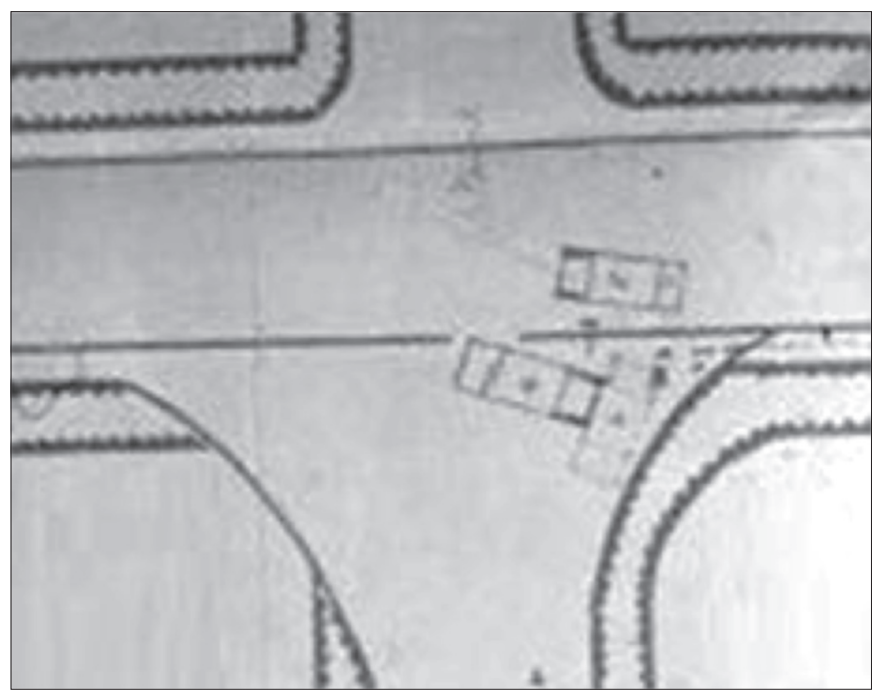

Obr. 2 Výřez z plánku ve spisu; konečné postavení Š100 a Octavie, stopa z obr. 10 (předjižděné vozidlo Š 1000 MB zastavilo normálním brzdèním dále mimo plánek).

Fig. 2 Excerpt from the map in the file; final position of Š100 and Octavia, track from Fig. 10 (overtaking vehicle Š 1000 MB stopped by normal braking further out of plan).

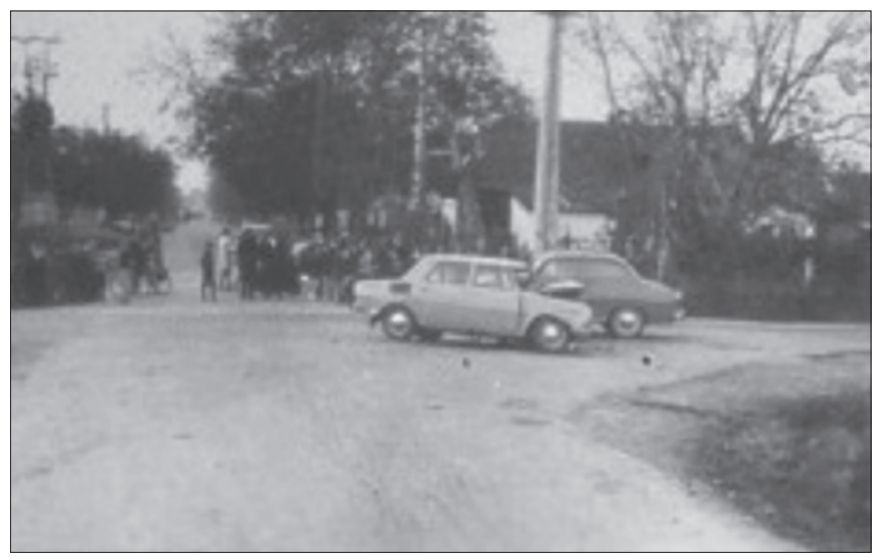

Obr. 3 Vozidla po nehodě, pohled ze směru jizdy vozidla Octavia. Vpředu škoda 100, jež puvodně předjižděla po hlavní silnici zprava, vzadu škoda Octavia.

Fig. 3 Vehicles after an accident, view from the direction of travel of the Octavia. At the front, the Škoda 100, which originally overtook the main road on the right, at the rear, the Škoda Octavia. na hlavní silnici ani nezastavila, jak přikazovala značka „Stůj, dej přednost v jízdě!“‘. Předjížděný řidič Š1000MB pak vypověděl, že v době střetu se $\mathrm{k}$ němu přiblížilo vozidlo Š100 a došlo k mírnému poškození jeho vozidla na levém boku vzadu; on po střetu zastavil plynule opodál.

- Verze řidiče Octavie: před hlavní silnicí zastavil, a když stál, přijelo zprava vozidlo Š100, jež při předjíždění vyjelo až na nezpevněnou část vozovky hlavní silnice a narazilo do jeho vozidla.

Vyšetřovací pokusy byly provedeny před zadáním ústavu, nejprve v obou verzích (obr. 6 až 9), podruhé už jenom ve verzi podle řidiče Octavie. Jedním z důkazů, majících potvrzovat verzi o vyjetí Š100 na krajnici, měla být smyková stopa na vyústění vedlejší silnice (obr. 10). Při znaleckém zkoumání fotografií

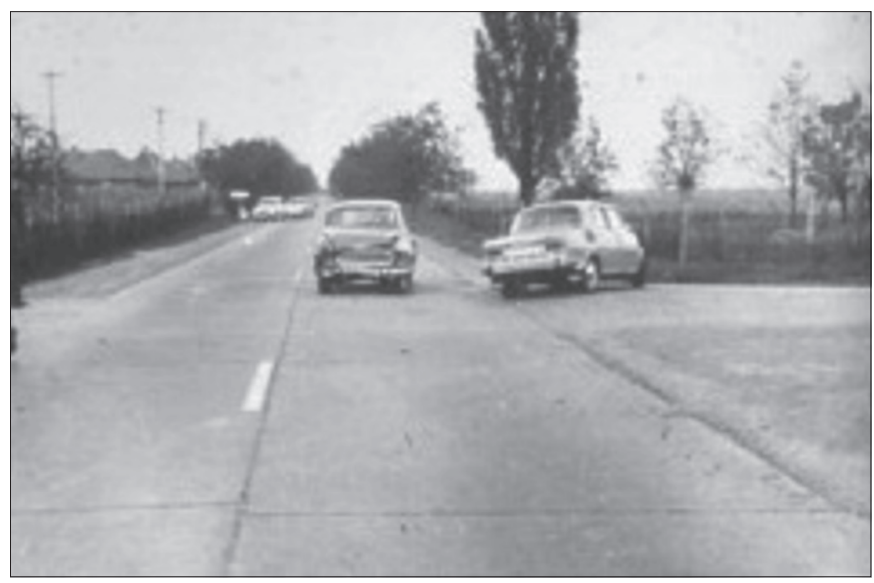

Obr. 4 Vozidla po nehodě. Vpravo Š 100, jež pưvodně předjižděla po hlavní silnici, vlevo Octavia, jež původně přijela z vedlejši silnice zleva.

Fig. 4 Vehicles after an accident. On the right $\breve{S} 100$, which originally overtook the main road, on the left Octavia, which originally came from the side road on the left.

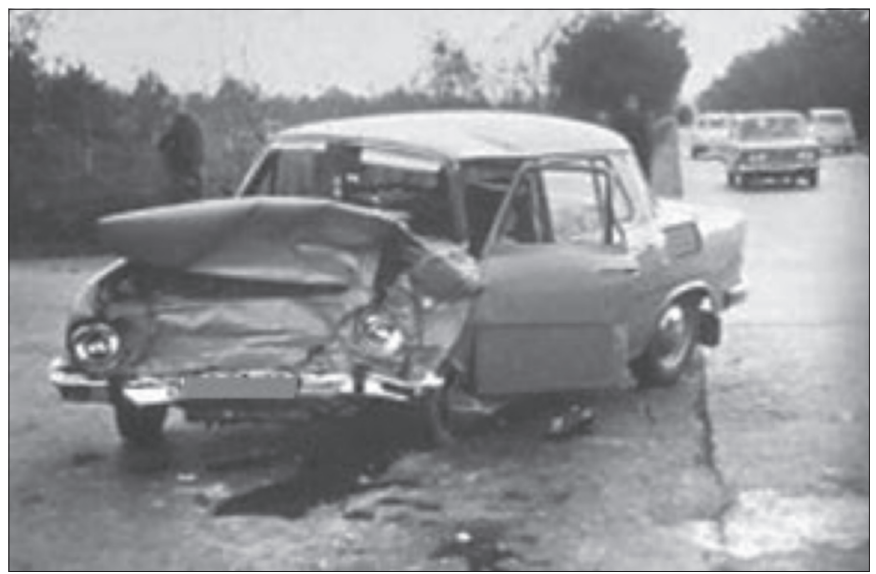

Obr. 5 Vozidlo Š 100, jež pưvodně předjiždělo na hlavní silnici, po nehodě otočené přibližně do protisměru, na vjezdu z vedlejši silnice, z niž prijizižděla Octavia. Na snímku zrèetelné střepiny a úlomky a kaluž kapaliny.

Fig. 5 Vehicle $\breve{S} 100$, which originally overtook the main road, after an accident turned approximately in the opposite direction, at the entrance from the side road from which the Octavia was coming. Clear fragments and fragments and a pool of liquid in the picture. 


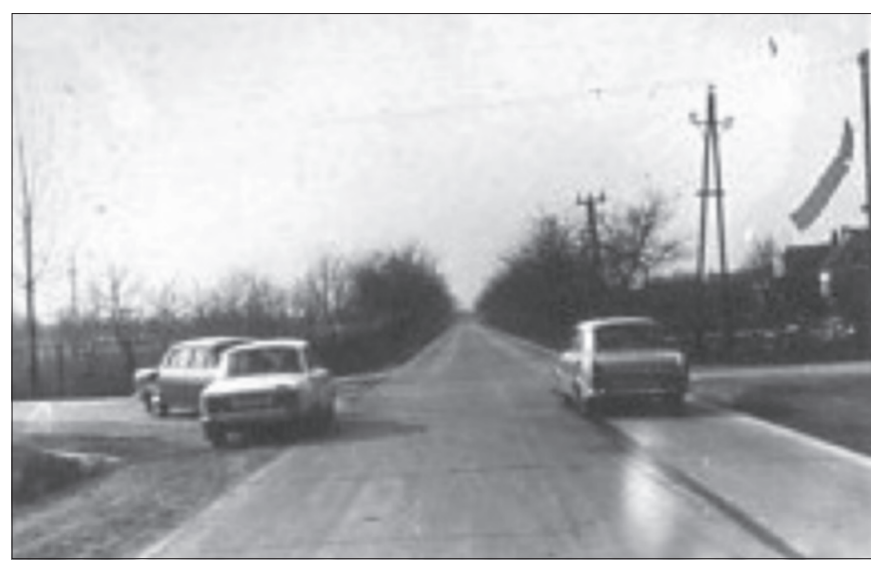

Obr. 6 Vyšetřovací pokus - vozidla v okamžiku střetu podle řidiče Octavie.

Fig. 6 Investigation attempt-vehicles at the moment of collision according to the driver Octavia.

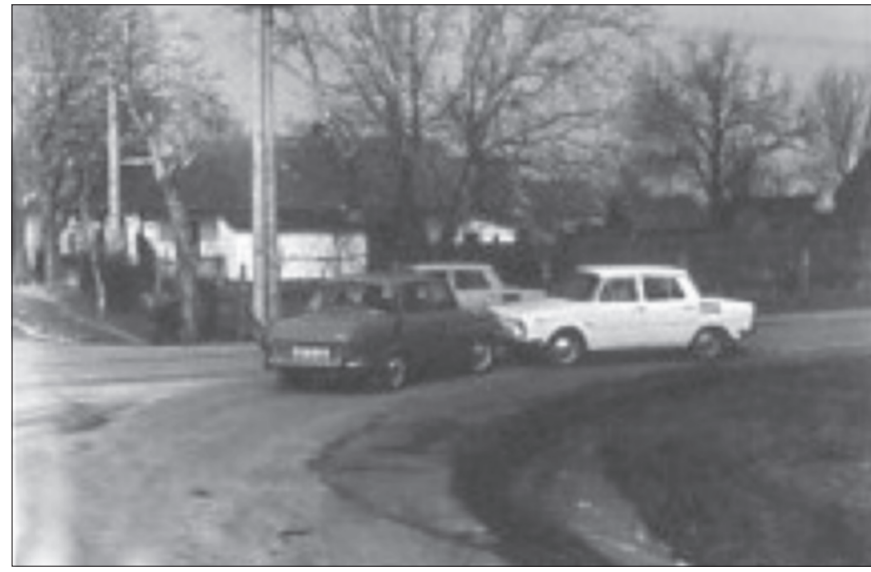

Obr. 7 Vyšetřovací pokus - vozidla v okamžiku střetu podle řidiče Octavie.

Fig. 7 Investigation attempt-vehicles at the moment of collision according to the driver Octavia.

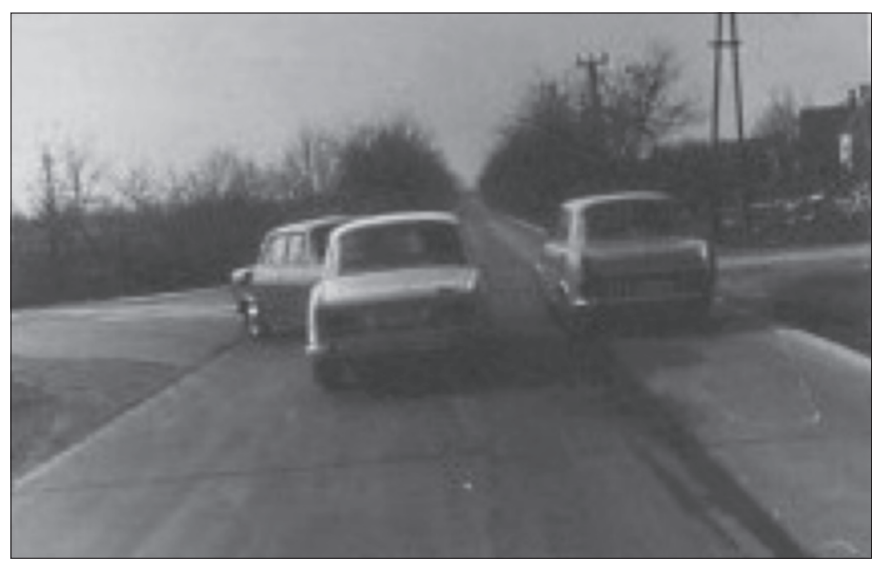

Obr. 8 Vyšetřovací pokus - vozidla v okamžiku střetu podle řidiče Š 100 .

Fig. 8 Investigation attempt-vehicles at the moment of collision according to the driver $\breve{S} 100$.

ve spisu však bylo zjištěno, že se na této fotografii nenacházejí žádné stř̌epy, jež v daném místě po nehodě byly (obr. 5). Byl proto na žádost znaleckého ústavu pozván na hlavní líčení technik VB,

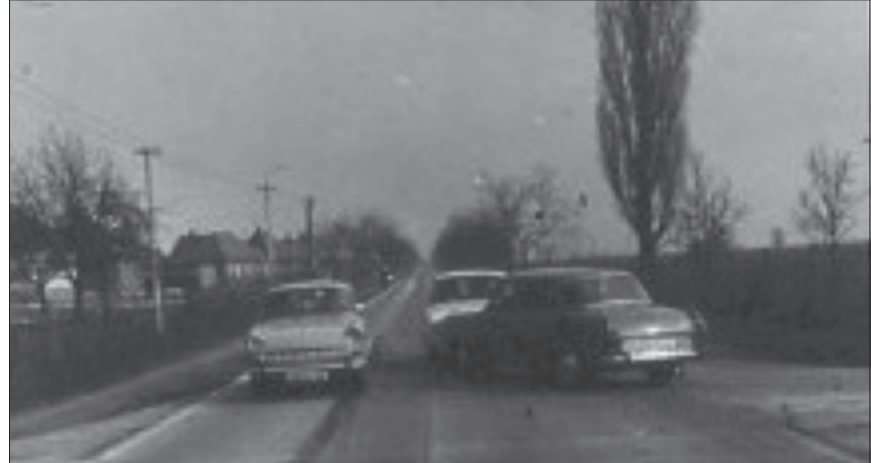

Obr. 9 Vyšetřovací pokus - vozidla v okamžiku střetu podle řidiče Š 100 .

Fig. 9 Investigation attempt-vehicles at the moment of collision according to the driver $\check{S} 100$.

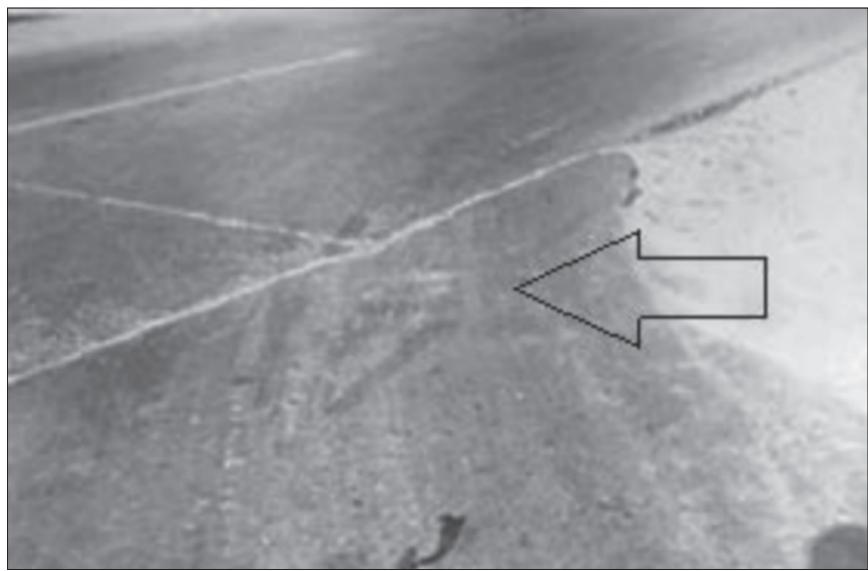

Obr. 10 Snímek stopy dodatečně zajištěný na vjezdu z vedlejši silnice, přisuzované vyšetřovatelem předjiždějicímu Š 100. Na snimku nejsou žádné střepiny.

Fig. 10 Image of the track additionally secured at the entrance from the side road, attributed by the investigator to the overtaking $\breve{S} 100$.

There are no shards in the image.

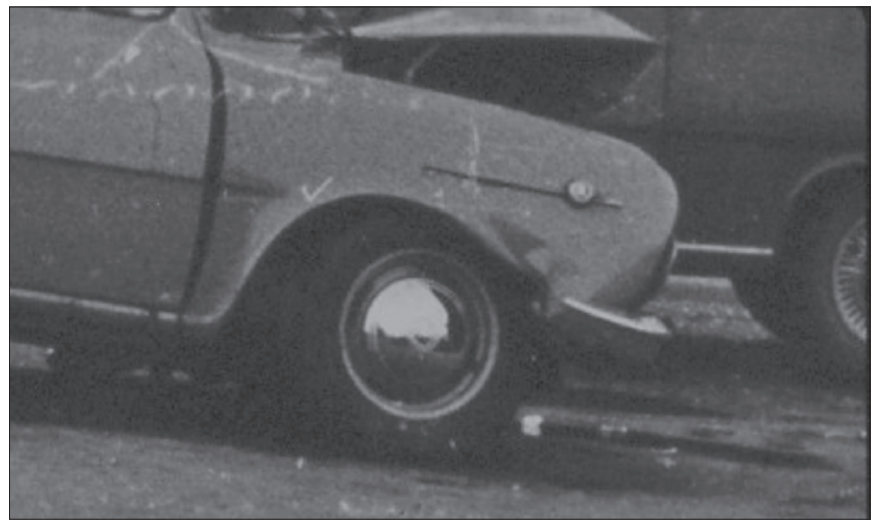

Obr. 11 Poškození pravého předního blatníku předjiždějicí Š 100. Fig. 11 Damage to the right front fender overtaking $\breve{S} 100$.

jenž fotografii stopy pořídil, a ten vypověděl, že fotografie byla pořízena jindy, později, když se snažili najít nějakou stopu, jež by vyhovovala verzi řidiče Octavie. 


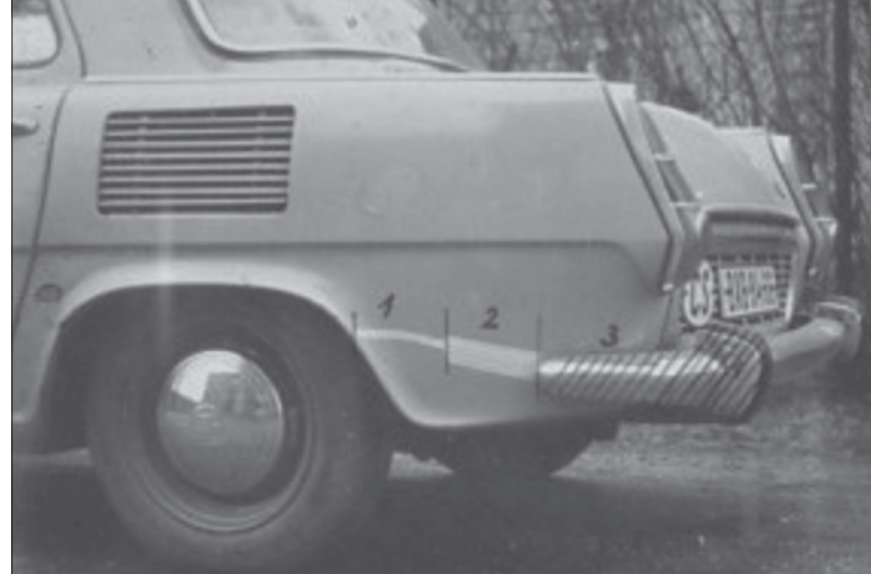

Obr. 12 Poškození předjižděného vozidla Š 1000 MB, jak je na dožádáni uvedl jeho řidič. 1 - roztrženo, 2 - promáčknuto, 3 - odtržená část nárazníku.

Fig. 12 Damage to the overtaken vehicle $\check{S} 1000$ MB, as stated by its driver on request. 1 -torn, 2 -dented, 3 -torn part of the bumper.

Na ústavu byla dále provedena zvětšenina ze snímku pravého předního blatníku Š100 (obr. 11), protože toto poškození neodpovídalo střetu s Octavií. Pro analýzu korespondence poškození byl na žádost ústavu požádán řidič Š1000MB, aby názorně specifikoval poškození jeho auta; dodán byl snímek, uvedený na obr. 12. Po porovnání korespondence poškození bylo zřejmé, že tato poškození způsobil střet s předjíždějícím vozidlem uhýbajícím doprava a zpomalujícím, které pak ovšem nemohlo být na krajnici.

Také zkoumáním snímku poškozeného čela Š100 byl v oblasti levého světlometu nalezen kruhový vtisk, odpovídající rámečku světlometu Octavie. Závěrem tedy bylo, že ke střetu došlo takřka čelně na hlavní silnici, na kterou vjela Octavie.

Z obdobných posudků vyplynula nutnost podrobnějších znalostí metrické analýzy obyčejných, neměřických fotografií; tomu se následně věnoval autor ve své kandidátské disertaci, zpracované pod vedením geodeta pana doc. Ing. dr. Josefa Zemana [9]. Rozvíjeny byly také názorné grafické metody analýzy včetně řešení otázky možností zabránění střetu při dřívější reakci řidiče nebo při nižší rychlosti jízdy (diagramy dráha-čas [1], otázka tří fází letu osob, předmětů resp. částí vozidel po odpoutání po střetu (tř̌i fáze: vodorovný resp. šikmý vrh po parabole, dopad se zrušením svislé složky rychlosti a sunutí do zastavení ev. do nárazu na nějakou překážku). Práce na metodice analýzy silničních nehod vyvrcholily kolem roku 1990 vydáním znaleckých standardů č. II až V, jež byly projednány $\mathrm{v}$ poradním sboru ministra spravedlnosti, následně pak schváleny a doporučeny Ministerstvem spravedlnosti [25 až 28].3)

Ještě k některým dalším mediálně známým nehodám, k nimž byl ústav pověřen zpracovat znalecké posudky. Dne 17. prosince 1982 zahynul na dálnici D1 u Devíti kř́žů (km cca 166,5) místopředseda vlády tehdejší ČSR, RSDr. JUDr. Zdeněk Zuska. Cestoval s řidičem směrem do Brna vozem Tatra 613, seděl na sedadle spolujezdce (i když měli prominenti doporučeno cestovat na sedadle zadním). Původní příčinou nehody byl vůz Tatra 603, jenž měl poruchu zadního kola a nouzově zastavil v prostoru výjezdu z parkoviště (obr. 13). Z parkoviště následně vyjížděl nákladní automobil JZD Slušovice, jenž vezl živá zvířata. Vzhledem k poloze T603 nemohl ovšem vyjet pomocí připojovacího pruhu, najížděl proto kolem T603 přes jízdní pruhy. Řidič vozidla T613 s dr. Zuskou usoudil, že nákladní automobil najíždí př́liš do vozovky a že tedy lepší bude podjet jej vpravo. Poté mu však nákladní automobil odkryl pohled na stojící T603, řidič T613 se proto rozhodl vyhnout přece jen doleva a nějak se vecpat mezi nákladní automobil a středová svodidla. Vzdálenost však již byla krátká na takové příčné přemístění, vozidlo narazilo pravou polovinou na zád' nákladního automobilu a zakleslo se pod něj až do prostoru spolujezdce natolik, že nebylo možno je urychleně vytáhnout. Zařízení proti vjezdu

\footnotetext{
3) Po změnách na Ministerstvu spravedlnosti po roce 1990 jevili pracovníci ministerstva snahu spíše se standardizaci vyhýbat, s tím, at' se toto řeší při jednotlivých kauzách.
}

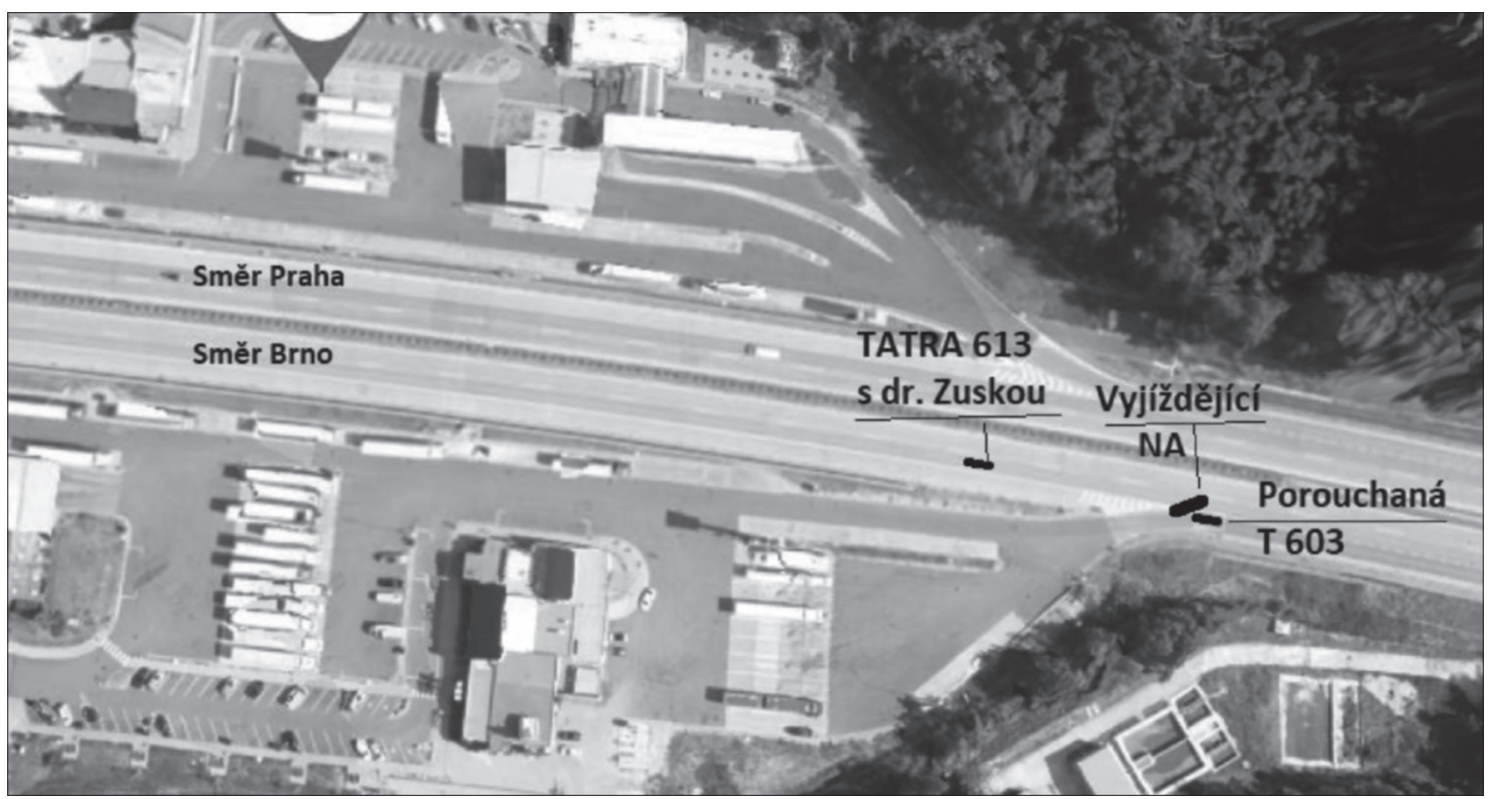

Obr. 13 Schéma situace těsně před nehodou dr. Zusky na D1 dne 17. prosince 1982 u Devíti Kř́žù (km 166,5).

Fig. 13 Diagram of the situation just before the accident dr. Zusky on D1 on December 17, 1982 at the Nine Crosses (km 166.5). 
vozidel proniklo až k nohám Z. Zusky, korba jej poranila natolik, že za delší chvíli zemřel; přivolaný lékař nezmohl nic víc, než že jej držel za ruku až do jeho konce. Střet přitom proběhl na relativně dlouhé dráze, řidič T613 vyvázl bez následků, poranění Z. Zusky byla mechanická, zádí nákladního automobilu. Byl proveden časový rozbor pro ověření přijatelnosti popisovaného děje a bylo také zjištěno, že původní rychlost T613 nepřekročila tehdy předepsaných 110 km/h (i když prý jako vládní vozidlo měla výjimku) $)^{4}$; nárazová rychlost T613 na zád' nákladního automobilu byla okolo $50 \mathrm{~km} / \mathrm{h}$.

Souběžně s analýzou nehod byla řešena související problematika oceňování motorových a jejich př́ípojných vozidel. Hlavním řešitelem byl pan Ing. Pavel Krejčíř, spolupracovali likvidátoři tehdejší České státní pojišt'ovny pod vedením pana Ing. Tomáše Matouška, mírně se podílel také autor tohoto příspěvku. Průběžně zde byla snaha tvưrců přiblížit výsledné ceny co nejvíce cenám, dosahovaným při prodeji ojetých vozidel (tehdy tradiční pojem „cena obecná“, kterou později autoři oceňovacích předpisů pro nemovitosti na Ministerstvu financí, neznalí tradiční metodiky, na doporučení tehdejšího ministra financí Václava Klause přejmenovali na cenu obvyklou). Bylo provedeno procentuální rozdělení jednotlivých druhů vozidel na skupiny podle ceny skupiny jako náhradního dílu $(100 \%=$ součet cen všech skupin jako náhradních dílů), způsob zjištění základní amortizace podle stáří a najetých kilometrů, odvozeny amortizační stupnice, rozpracovány další detailnější postupy $\mathrm{k}$ dosažení technické hodnoty vozidla v \% a v korunách a způsob stanovení koeficientu prodejnosti pro přepočet na cenu obecnou/obvyklou. Práce nakonec byly základem pro vydání znaleckého standardu č. I [24].

Metodika oceňování vozidel byla ve velkém využita $\mathrm{v}$ době náběhu výroby vozidel Škoda 742 (105/120) v osmdesátých letech 20. století v továrně AZNP (nyní ŠKODAAUTO) Mladá Boleslav. Při náběhu výroby přidělil tehdejší ředitel AZNP Miroslav Zapadlo velké množství vozidel ze sériové výroby ke zkušebním jízdám osobám mimo AZNP, zejména prominentům. Vozidla měla zvláštní

4) Ověření přijatelnosti popisovaného děje bylo nutné také vzhledem k tomu, že Z. Zuska byl odpůrcem JZD Slušovice, jehož byl nákladní automobil, a začaly se vynořovat spekulace, že se jednalo o zinscenovanou nehodu, také proto, že v dané době zde bylo i vozidlo StB, i když za jiným účelem.

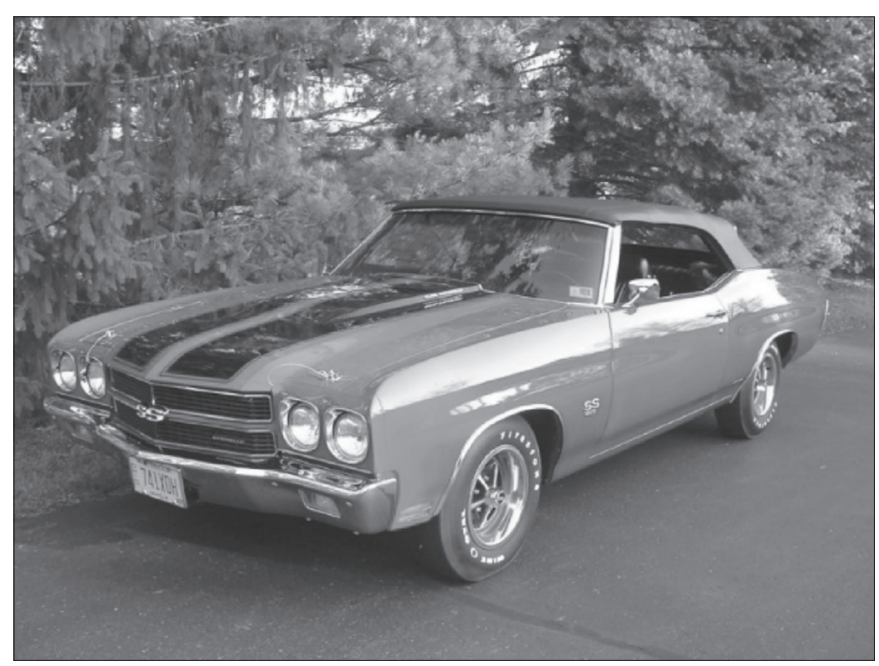

Obr. 14 Chevrolet Malibu 1970 [https://www.google.com/...]. Fig. 14 Chevrolet Malibu 1970 [https://www.google.com/...].
SPZ s písmenem F, jež opravňovala nedodržovat na dálnici tehdy danou max. rychlost 110 km/h. Řidič si musel hradit benzin, žádné nájemné nebylo stanoveno. Každé tři měsíce byl řidič povinen poslat do továrny zprávu o provozu a zjištěných ev. problémech, při závažnějších zjištěních okamžitě.

Kontrolou tehdejšího Výboru lidové kontroly (obdoba nynějšího Nejvyššího kontrolního úrúadu) bylo zjištěno, že skoro žádný uživatel svěřeného zkušebního vozidla povinná hlášení neposílal a většina jich vozidla užívala k soukromým jízdám. Bylo proto nařízeno všechna vozidla okamžitě vrátit do továrny $\mathrm{s}$ tím, že po ocenění budou prodána. Oceněním těchto řady desítek vozidel byl pověřen ÚSI.

Smutným byl případ revize posudků na stanovení škody na automobilu Ford Malibu (obr. 14), poškozeném při natáčení slovenského televizního filmu „Ztratená“. V předmětné scéně měl jet známý slovenský herec se spolujezdkyní po doleva se zatáčející cestě kolem okraje lesa; kamera (ještě na klasický film $35 \mathrm{~mm}$ ) byla umístěna $\mathrm{v}$ lese. $\mathrm{V}$ daném místě měl řidič zastavit a spolujezdkyni vysadit z auta. Po několikerém opakování stejných záběrů při dalším najednou řidič nezastavil, vyjel z cesty doprava (tedy vlastně po tečně) a sjel šikmo do nedaleké souběžné př́íkopy, na jejíž protilehlý svah šikmo s vozidlem narazil. Řidič ani spolujezdkyně přitom neutrpěli vážnější zranění. Automobil byl televizi zapůjčen na smlouvu od tehdy známého sběratele veteránů, jenž si nechal udělat znalecký posudek a požadoval náhradu vzniklé škody. Ohledání místa nehody provedli př́slušníci SNB, kteří vyhotovili kompletní záznam o dopravní nehodě včetně fotodokumentace.

Znalecký posudek ohledně výše škody na automobilu vypracoval tehdejší předseda poradního sboru znalců pro nehody a oceňování vozidel předsedy krajského soudu, hlavním povoláním vedoucí dopravního odboru KNV; byl to jeden z jeho prvních posudků, předběžné znalecké vzdělání neměl. Jako výchozí cenu použil cenu podle znalce tehdy srovnatelného vozidla Tatra 603-2 ve výši 160000 Kčs (škodovka stála tehdy okolo 40000 Kčs). Dále použil přirážky, např́klad za kotoučové brzdy, i když na fotografii ve spisu SNB byla př́mo fotografie obnažených brzdových čelistí předního kola Malibu s demontovaným bubnem; také počet válců motoru podle posudku byl jiný než ve skutečnosti. Dále bylo podle posudku zcela poškozeno:

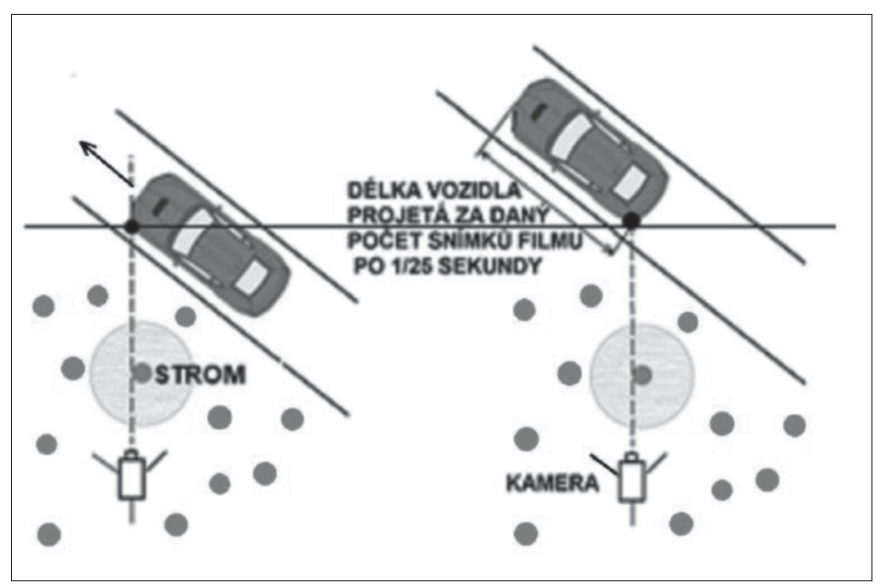

Obr. 15 Schéma stanovení rychlosti vozidla z filmového záběru jízdy (bez méritka).

Fig. 15 Scheme for determining the speed of a vehicle from a movie scene (without scale). 
- všech 5 kol (včetně náhradního!),

- motor, převodovka, spojovací hřídel, rozvodovka,

- přední i zadní náprava,

- karoserie,

- na př́istrojové desce jednotlivé přístroje, které se tam snad ani nemohly vejít.

Vzhledem k vysoké částce znalcem stanovené škody (prakticky totální škoda) si televize vyžádala revizní posudek, který vypracoval místopředseda poradního sboru, rovněž znalec v letech, a to obdobným způsobem. Televize byla nakonec odsouzena škodu uhradit; následovalo trestní oznámení. Oba znalci byli na Velikonoce v noci zadrženi a vzati do vazby s kvalifikací „křivá výpověd” a nepravdivý znalecký posudek“ a „rozkrádání majetku v socialistickém vlastnictví“. Při výslechu mj. oba tvrdili, že vozidlo osobně prohlédli, a na tom setrvali až do konce (výsledkem byl trestný čin úmyslný, nikoliv nedbalostní).

Znalecký posudek byl po rok trvajícím trestním řízení (oba znalci stále ve vazbě) soudem zadán Ústavu soudního inženýrství VUT v Brně; požadováno bylo vyjádření jak k průběhu havárie vozidla, tak k výši škody. Po studiu spisu bylo vyžádáno ohledání zbytků vozidla; bylo ovšem zjištěno, že vlastník vozidlo s údajnou totální škodou nesešrotoval, ale prodal za 40000 Kčs. Prohlídkou bylo zjištěno, že na vozidle byly provedeny jen drobné opravy, spíše kosmetické; např́iklad chromované rámečky světlometů byly jen narovnány, interiér byl zcela původní, takže o totální škodu se evidentně nejednalo. Při následném výpočtu výše škody ovšem bylo uvažováno, že co nebylo prohlídkou možno ověřit, poškozeno bylo (,,in dubio pro reo - v pochybnostech ve prospěch“), ale i tak vyšla výsledná výše škody podstatně nižší.

Zajímavá byla situace kolem analýzy vzniku a průběhu havárie, zejména stanovení rychlosti vozidla. Televizí byla dodána kopie filmu se záznamem jízdy vozidla, kdy kamera byla umístěna v lese a vozidlo jelo po jeho okraji (schematicky na obr. 15). Bylo zjištěno, že než na stejné místo při pohledu za konkrétním stromem, kde je $\mathrm{v}$ určitém čase přední část vozidla, dojede zadní část, posune se film o 11 políček. Při frekvenci filmu 25 snímků za sekundu reprezentuje jedno políčko čas $1 / 25=0,04$ sekundy, celkem tedy 11 $\times 0,04=0,44$ sekundy. Při délce vozidla 4,925 metru pak vychází rychlost $v=s / t=4,925 / 0,44=11,2 \mathrm{~m} / \mathrm{s}=40,3 \mathrm{~km} / \mathrm{h}$. (Př̀ hlavním líčení namítala obhajoba, že je to špatně, poněvadž délka vozidla byla při šikmém pohledu zkreslena; závěry si jistě udělá čtenář sám.)

Závěrem netypická nehoda, související s „dočasným“ pobytem sovětských vojsk. V Mladé Boleslavi jel řidič s manželkou v osobním automobilu. Když projížděli levotočivou zatáčkou, jel proti nim nákladní automobil sovětské armády, jemuž podle výpovědi řidiče osobního automobilu ze skřriňky, nacházející se pod ložnou plochou, vypadl hever (zřejmě odstředivou silou), dopadl na vozovku, odrazil se svisle nahoru a aniž poškodil předek osobního automobilu, proletěl jeho předním sklem, těžce poranil spolujedoucí manželce krk a vyletěl zadním oknem. Řidič osobního automobilu ani nezastavil, jel rovnou do nemocnice, ale manželku již nezachránili. Řidič sovětského nákladního automobilu o incidentu nevěděl, pokračoval v jízdě. Řidič osobního automobilu se z nemocnice vrátil na místo nehody, ale hever (předmět doličný) již mezitím zmizel (žrejmě jej mezitím někdo ukradl).

Při výslechu tentýž den řidič sovětského nákladního automobilu přiznal, že ve skř́iňce hever měl; druhý den však přišli jeho spolubojovníci s tím, že jejich řidič nevěděl, že oni si hever vypůjčili, takže jej tam neměl, takže z jejich automobilu nemohl vypadnout, když tam nebyl. Řidiči pak hned nato údajně skončil pobyt v ČSSR a byl poslán zpět do SSSR.

Úkolem ústavu bylo ověřit technickou přijatelnost výpovědi řidiče osobního automobilu, zda je možné, aby hever po vypadnutí z nákladního automobilu po odrazu od silnice vyletěl až do výšky čelního skla osobního automobilu, tedy zejména zda k tomu měl dostatečnou energii. ${ }^{5)}$ Bylo prrikročeno k experimentu, kdy na letištní ploše se pohyboval nákladní automobil, ze kterého byl z odpovídající výšky vodorovně vyhazován hever a jízda se natáčela kamerou; $\mathrm{v}$ jednom př́ípadě $\mathrm{k}$ popisovanému pohybu skutečně došlo.

\section{LITERATURA}

[1] BRADÁČ, A. Početně grafické řešení vzniku a průběhu silniční nehody. 1974, 1978.

[2] SMRČEK, J. Základy soudního inženýrství. 1975.

[3] JAROŠEK, V. Autoopravárenství. 1976.

[4] SCHWARZ, J. Přehled elementární matematiky a fyziky. 1976.

[5] BALÁŠ, S. Elektrotechnika v autoopravárenství. 1978.

[6] PORADA, V., BRADÁČ, A., Kriminalisticko-technická dokumentace. 1978.

[7] FRIML, K. Občanské právo. 1978.

[8] HELEŠIC, V. Základy trestního práva, 1978.

[9] BRADÁČ, A. Problematika měřické dokumentace pro technické zkoumáni havárií. Kandidátská disertace, 1978.

[10] KREJČÍŘ , P. a kol. Komplexni ověřování opravitelnosti karoserii osobnich automobilì po haváriích. 1980.

[11] NAVRÁTIL, D. Autoopravárenství. 1982.

[12] ك̌MOLÍK, V. Dopravní inspektoráty. 1983.

[13] MEDUNA, P. Nauka o materiálu. 1983.

[14] BRADÁČ, A. Teorie technické analýzy silniční nehody (problémové úlohy). 1983.

[15] MEDUNA, J. Aplikovaná mechanika. 1984.

[16] BRADÁČ A. a kol., Přriručka znalce-Analytika silničních nehod I a II. 1985.

[17] BRADÁČ, A., KREJČÍŘ, P. a kol. Technicko právní problematika inženýrské práce. 1985.

[18] BRADÁČ, A. Katalog vozidel - I. a II. dil. 1985.

[19] BRADÁČ, A. Interní pokyny pro zpracování znaleckých posudkü. 1986.

[20] BRADÁČ, A. Soudní inženýrství. Učební text PGS, 1987.

[21] BRADÁČ, A. Vybrané problémy soudního inženýrství při analýze silničnich nehod. Doktorská disertační práce. VUT v Brně - ÚSI, VŠDS Žilina, 1988.

[22] NOP, D. Ŕzizení dopravy a psychologie řidiče. 1988.

[23] NAVRÁTIL, D. Technologie autoopravárenství. 1989.

[24] KREJČÍŘ, P., BRADÁČ, A. Znalecký standard č. I-Oceňování motorových vozidel. 1990, 2. aktual. vyd. 2004.

[25] BRADÁČ, A., KREJČÍŘ, P., GLIER, L. Znalecký standard č. II - Vybrané metody zajišt'ováni podkladi̊ pro technickou analýzu průběhu a př́čin silničnich dopravnich nehod. 1990.

[26] BRADÁČ, A. a kol. Znalecký standard č. III - Technická analýza střetu vozidla s chodcem. 1991.

\footnotetext{
5) Na zpracování posudku se podílel posluchač, jenž byl aktivním hráčem ragby; uváděl, že v ragby existuje kop, kdy se míč po dopadu na terén odazí prakticky svisle.
} 
[27] BRADÁČ, A., GLIER, L. Znalecký standard č. IV-Technická analýza nárazu vozidla na překážku. 1991.

[28] BRADÁČ, A. a kol. Znalecký standard č. V-Zjišstování a posuzováni technického stavu vozidel pro technickou analýzu průběhu a př́icin silničnich dopravnich nehod. 1992.

[29] BRADÁČ, A. a kol. Soudní inženýrství. 1997.

[30] KAPLÁNEK, A., PTÁČEK, P. Přeprava nákladu v silniční nákladni dopravě. 2002.

[31] BRADÁČ, A. a kol. Úvod do soudního znalectví. 2004.

[32] BRADÁČ, A., KLEDUS, M., KREJČÍŘ, P. Soudní znalectví. 2010.
[33] SEMELA, M. Analýza silničnich nehod I., II. 2012.

[34] PANÁČEK, V. Zkoušení vozidel. Brno. 2012.

[35] KLEDUS, R. Obecná metodika soudního inženýrství. 2012.

[36] BRADÁČ, A. Vybrané právni předpisy k problematice SI a obecných zásad oceňování majetku $v \check{C} R$. 2016.

[37] BRADÁČ, A., KREJČÍǏr, P., VÉMOLA, A., WEIGEL, L., BRADÁČ, A. Soudní znalectví ve vybraných technických a ekonomických oborech. 2018.

\section{Správná citace:}

BRADÁČ, A. Z historie Ústavu soudního inženýrství Vysokého učení technického v Brně - III. Soudní inženýrství, 2020, 31(3), 31-39. DOI: http://dx.doi.org./10.13164/SI.2020.4.31. ISSN 1211-443X.

\section{Přehled konferencí 2021}

\section{Preparing Conferences 2021}

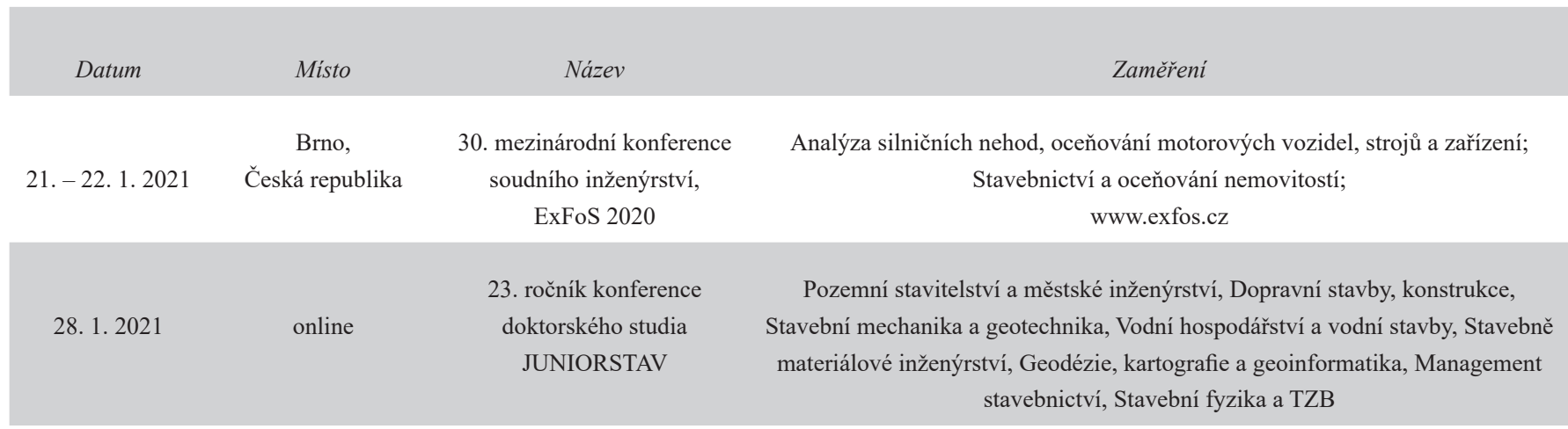

Brno,

17. - 20.2.2021 Česká republika

Stavební veletrh
Realizace staveb, stavební řemesla, TZB, stavební materiály, stavební konstrukce;

www.bvv.cz/stavebni-veletrh-brno/

\begin{tabular}{|c|c|c|c|}
\hline 3. -5.3 .2021 & $\begin{array}{l}\text { Hustopeče u Brna, } \\
\text { Česká republika }\end{array}$ & $\begin{array}{l}\text { 15. ročník symposia Týdne } \\
\text { výzkumu a inovací pro praxi } \\
\text { a životní prostředí - } \\
\text { TVIP } 2020 / 2021\end{array}$ & $\begin{array}{c}\text { Průmyslová a komunální ekologie, materiálové, biologické a energetické využití } \\
\text { odpadů, nebezpečné odpady, sanace ekologických zátěží a následků havárií, } \\
\text { recyklace vody, řízení průmyslových rizik a rovněž na rizika při správě regionů, } \\
\text { měst a obcí; } \\
\text { www.tretiruka.cz/konference/ }\end{array}$ \\
\hline
\end{tabular}

Uherské Hradiště, Česká republika

\section{Mezinárodní konference}

Krizové řízení a řešení

krizových situací CRISCON
Analýza rizik, Environmentální bezpečnost, Ochrana obyvatelstva, Logistika a doprava;

https://criscon.cz/ 